\title{
Chronic effects of endosulfan on acetylcholinesterase and cellulase enzyme activity of earthworm eisenia foetida
}

\begin{abstract}
Pesticides produces considerable effects on biochemical parameters of organisms and since enzymes allow specific reactions to proceed and collectively constitute the metabolism, studies on metabolic enzymes and proteins of earthworms may be useful biomarkers for ecotoxicological aspects. Endosulfan, belonging to the organochlorine group of pesticides on growth, reproduction and avoidance behavior of earthworm E. foetida and found that the pesticide significantly affected the parameters. Due to its used against a broad spectrum of insects and mites in agriculture and allied sectors, it is one of the most extensively used pesticides in the agricultural fields of MP, Central India. The present study has been undertaken to reveal its chronic effects on two important enzymes, i.e. Acetylcholinesterase and Cellulase of earthworm E. foetida. Both the enzymes have their own significance in earthworm physiology. The inhibition of AchE activity was found to be concentration dependent. During the exposure period of 28days the percent of AchE activity was found as $43 \%, 51 \%$ and $68 \%$ at doses of $0.5,1$ and $2 \mathrm{mg} / \mathrm{kg}$ endosulfan whereas, during the exposure period of 30 to 90 days same doses caused inhibition of AchE activity up to $25 \%, 39 \%$ and $63 \%$ after first 30days of exposure and no significant changes or recovery of enzyme activity was observed after 90days of exposure. Therefore, from the present findings it can be concluded that long term exposure to organochlorine pesticides could lead to severe and irreparable effects on biochemical mechanisms of earthworms.
\end{abstract}

Volume 3 Issue 3 - 2017

\author{
Sameena Farrukh \\ National Institute of Technical Teachers Training \& Research, \\ India
}

Correspondence: Sameena Farrukh, National Institute of Technical Teachers Training \& Research, Bhopal, 462002, India, Tel 9630667602, Email sameenafarrukh04@gmail.com

Received: June 12, 2017| Published: July 07, 2017

\section{Introduction}

Biological sensitivity to contaminant concentrations may vary substantially from species to species and the mode of toxic action may be highly selective and impair specific biological functions of the organisms. Physiological activities i.e. respiration, metabolism, feeding, breeding etc, of aquatic invertebrates are inhibited by the effects of pesticides. ${ }^{1}$ Various workers have shown that earthworm have been considered useful bioindicators of land use, soil fertility, and soil ecosystem health, studies have shown that worms can accumulate high concentrations of pesticides, and therefore they have been used as bioindicators of soil pollution by metals and pesticides. ${ }^{2,3}$ The ecological divergences in life style of earthworms provide an excellent platform to explore possible links between physiology and ecology at biochemical level. ${ }^{4}$ Pesticides produces considerable effects on biochemical parameters of organisms and since enzymes allow specific reactions to proceed and collectively constitute the metabolism, studies on metabolic enzymes and proteins of earthworms may be useful biomarkers for ecotoxicological aspects. ${ }^{5}$ Few studies have examined the impact of confounding factors on earthworm ChE activity. The earthworm age (1,2 and 3 months old) and soil type (loamy, sandy and clay soils) did not affect CHE activity, where as soil temperature has marked effects. Moreover, earthworms are among the organisms that show the slowest recovery rates, in terms of several months, of phosphorylated effects. This extremely slow recovery makes CHE inhibition an excellent biomarker of pesticide contamination ChE. ${ }^{6,7}$ Farrukh et al., ${ }^{8}$ studied the effects of Endosulfan, belonging to the organochlorine group of pesticides on growth, reproduction and avoidance behavior of earthworm $E$. foetida and found that the pesticide significantly affected the parameters. Due to its used against a broad spectrum of insects and mites in agriculture and allied sectors, it is one of the most extensively used pesticides in the agricultural fields of M.P., Central India. The present study has been undertaken to reveal its chronic effects on two important enzymes, i.e. Acetylcholinesterase and Cellulase of earthworm $E$. foetida. Both the enzymes have their own significance in earthworm physiology.

\section{Material and methods}

Culture, acclimatization and calculation of LC 50 was done as per the method of Farrukh et al. ${ }^{8}$ After calculation of LC50 which was found to be $3.57 \mathrm{mg} / \mathrm{kg}$ dry weight of soil the sub lethal doses of Endosulfan were selected as $0.5,1$ and $2 \mathrm{mg} / \mathrm{kg}$ dry weight of soil and were coded as E0(control), E1(0.5mg/kg), E2 $(1 \mathrm{mg} / \mathrm{kg})$ and E3 $(2 \mathrm{mg} /$ $\mathrm{kg}$ ). The first set of experiments for short term study was conducted at regular 7days intervals i.e. 7, 14, 21 and 28days on two different groups of earthworms namely endosulfan exposed group called short term endosulfan (STE). Similarly the second sets of experiments for long term study was divided into two major groups called long term endosulfan (LTE) and were conducted at intervals of 30, 45, 60 and 90 days. All the above experiments were conducted with well matched controls maintained under similar conditions.

\section{Extraction of enzymes}

Following the method of Mishra et al., ${ }^{9}$ with slight modifications earthworms taken for enzyme estimation were kept in moist filter paper for $24 \mathrm{hrs}$ to void their gut contents and then homogenized $(10 \% \mathrm{w} / \mathrm{v})$ in $0.1 \mathrm{M}, \mathrm{pH} 7.5$ phosphate buffer. For Cellulase estimation the homogenates were centrifuged at $2,500 \mathrm{rpm}$ for $10 \mathrm{~min}$, the 
supernatant fluid was removed into another centrifuge tube and were centrifuged at $3000 \mathrm{rpm}$ for $5 \mathrm{~min}$, the supernatant fluid was collected and used to test enzyme activity. For Acetyl Cholinesterase activity, the homogenates cooled up to $4^{\circ} \mathrm{C}$ were centrifuged at $10,000 \mathrm{rpm}$ for $10 \mathrm{~min}$ and the resultant supernatant was recentrifuged at $10,000 \mathrm{rpm}$ for 10min (name of the centrifuge model) and supernatant was stored in ice for AchE activity. ${ }^{10}$

\section{Determination of cellulase activity}

Cellulase activity was determined by following the method of Mishra et al., ${ }^{9}$ with little modifications. Incubate $1 \mathrm{ml}$ of cellulose solution, $1 \mathrm{ml}$ of Cellulase extract and $1 \mathrm{ml}$ of phosphate buffer $(\mathrm{pH}$ 6.4 ) in a test tube for $24 \mathrm{hrs}$. The enzyme activity was measured using the DNS method when $1 \mathrm{ml}$ of working DNS reagent was added to each test tube covered with a marble and kept in boiling water bath for $5 \mathrm{~min}$, cool it and absorbance was measured against a suitable blank. The activity of cellulase was measured in terms of mgs of glucose/ $\mathrm{hr} /$ per mg body proteins by plotting the linear regression curve with glucose standards.

\section{Determination of acetyl cholinesterase activity}

Acetyl Cholinesterase activity was determined following the method. ${ }^{11}$ The assay consists of $2.8 \mathrm{ml}$ of $0.1 \mathrm{M}$ phosphate buffer $\mathrm{pH} 7.2$, $50 \mu 1$ of $0.16 \mathrm{mM}$ DTNB, $50 \mu$ lof protein and $100 \mu$ l of 0.2 ACT iodide as substrate. The reactions were performed at $37^{\circ} \mathrm{C}$ and were initiated by adding the substrate (ACT iodide). The measurement of rate of production of thiocholine was accomplished by measurement of the continuous reaction of the thiol with DTNB to produce the yellow anion of 5-thio-2-nitrobenzoic acid. The rate of color production was recorded for $6 \mathrm{~min}$ at $412 \mathrm{~nm}$ in a spectrophotometer. The activity was calculated as $\mu \mathrm{mol} / \mathrm{mg}$ protein $/ \mathrm{min}$.

\section{Statistical analysis}

Statistical significance of all the values observed during the experiments were analyzed by comparing the values with their relevant controls at $95 \%$ confidence interval at significance of $p<(0.05)$ and $\mathrm{p}<(0.001)$ using NCSS, (2007) version 7.1.14 statistical software.

\section{Results}

\section{Cellulase activity ( $\mathrm{mg}$ of glucose/mg of protein/hr)}

As evident from the data of (Table 1) (Figure 1) there was a marked decrease in Cellulase activity in all the groups of earthworms when they were exposed to different concentrations of endosulfan i.e. E1, E2, and E3 except the control group E0 over the period of 28days. Earthworms of group E1 i.e. $0.5 \mathrm{mg} / \mathrm{kg}$ endosulfan exhibited an initial decline in Cellulase activity after 7days from the control value of $61.95 \pm 1.80$ to $41.64 \pm 0.44$ which further decreased up to $38.15 \pm 0.65$ after the exposure period of 28days. At the dose of $1 \mathrm{mg} / \mathrm{kg}$ there was decrease in mean Cellulase activity of earthworms from control value of $61.95 \pm 1.80$ to $41.64 \pm 0.44$ (mg of glucose $/ \mathrm{mg}$ of protein $/ \mathrm{hr}$ ) after first week of exposure which further decreased up to $47 \%$ from control value after 28 days of exposure. Whereas, the highest dose of $2 \mathrm{mg} / \mathrm{kg}$ brought down the mean Cellulase activity to $19.53 \pm 0.93$ after 7 days and further decreased up to $27 \%$ after 28 days. All the values obtained from exposed groups were found to be significantly different at $(p<0.001)$ from their relevant controls.
Table I Showing the cellulase activity (mg of glucose/mg of protein/ hr.) of earthworms in during 7, 14, 21 and 28days of exposure to different concentrations of endosulfan (mean \pm S.E where $n=9$ ).

\begin{tabular}{|c|c|c|c|c|}
\hline Dosage & 7 Days & I4 Days & 2 I Days & 28 Days \\
\hline $\mathrm{EO}$ (control) & $61.95 \pm 1.80$ & $65.08 \pm \mid .21$ & $62.85 \pm 1.93$ & $64.06 \pm 1.73$ \\
\hline $\begin{array}{l}\mathrm{El}(0.5 \mathrm{mg} / \\
\mathrm{kg})\end{array}$ & $41.64 \pm 0.44$ & $4 I .7 I \pm 0.55$ & $38.54 \pm 0.31$ & $38.15 \pm 0.65$ \\
\hline E2 $(\mathrm{Img} / \mathrm{kg})$ & $30.26 \pm 0.60$ & $31.38 \pm 0.72$ & $30.83 \pm 0.96$ & $30.18 \pm 0.76$ \\
\hline E3 $(2 \mathrm{mg} / \mathrm{kg})$ & $19.53 \pm 0.93$ & $18.48 \pm 0.56$ & $* 18.73 \pm 0.35$ & $* 17.63 \pm 0.50$ \\
\hline
\end{tabular}

$*(\mathrm{p}<0.00 \mathrm{I})$

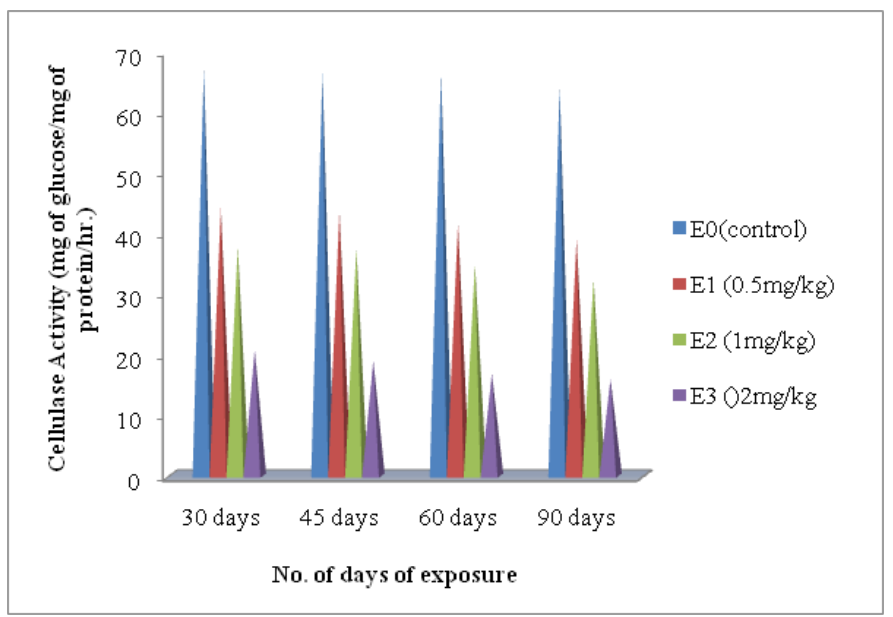

Figure I Showing the change Cellulase enzyme activity (mg of glucose/mg of protein/hr.) of earthworms during $7,14,21$ and 28 days of exposure to different concentrations of endosulfan with well matched control earthworms.

\section{Cellulase activity ( $\mathrm{mg}$ of glucose/mg of protein/hr)}

According to the data of (Table 2), (Figure 2) a remarkable drop down change in Cellulase activity in all the groups of earthworms was observed when they were exposed to different concentrations of endosulfan i.e. E1, E2, and E3 except the control group E0 over the period of 90days of experiment. As shown in (Table 2), (Figure 2) the earthworms of group E1 i.e. $0.5 \mathrm{mg} / \mathrm{kg}$ endosulfan exhibited an initial decline in Cellulase activity after 30days from the control value of $67.13 \pm 0.46$ to $44.16 \pm 2.19$ and at the dose of $1 \mathrm{mg} / \mathrm{kg}$ there was decrease in mean Cellulase activity of earthworms from control value of $67.13 \pm 0.46$ to $37.78 \pm 0.95$ ( $\mathrm{mg}$ of glucose/mg of protein/ hr). Similarly, as evident from the data of (Table 2), (Figure 2) the highest dose of $2 \mathrm{mg} / \mathrm{kg}$ brought down the mean Cellulase activity from control value of $67.13 \pm 0.46$ to $20.77 \pm 0.29$ after 30days of exposure. Further decline in the values after 90days of exposure at all the three doses of endosulfan i.e. $0.5,1 \mathrm{and} 2 \mathrm{mg} / \mathrm{kg}$ were observed as $39.12 \pm 0.66,32.45 \pm 1.07$ and $15.93 \pm 0.55$ ( $\mathrm{mg}$ of glucose $/ \mathrm{mg}$ of protein/hr). Whereas no significant change in the control values were observed during the entire period of experiment. 
Table 2 Showing the AchE activity ( $\mu \mathrm{moles} / \mathrm{mg}$ of protein $/ \mathrm{min}$.) of earthworms during 30, 45, 60 and 90 days of exposure to different concentrations of endosulfan (mean \pm S.E where $n=9$ ).

\begin{tabular}{lllll}
\hline Dosage & $\mathbf{3 0}$ Days & $\mathbf{4 5}$ Days & $\mathbf{6 0}$ Days & $\mathbf{9 0}$ Days \\
\hline $\mathrm{E} 0($ control $)$ & $76.52 \pm 0.27$ & $76 \pm 0.38$ & $75.72 \pm 0.50$ & $74.89 \pm 0.44$ \\
$\mathrm{EI}(0.5 \mathrm{mg} / \mathrm{kg})$ & $57.64 \pm 0.37$ & $52.44 \pm 0.62$ & $53.03 \pm 0.49$ & $54.01 \pm 0.48$ \\
$\mathrm{E} 2(\mathrm{Img} / \mathrm{kg})$ & $46.85 \pm 0.67$ & $43.03 \pm 0.57$ & $40.86 \pm 0.40$ & $* 40.74 \pm 0.37$ \\
$\mathrm{E} 3(2 \mathrm{mg} / \mathrm{kg})$ & $* 37.06 \pm 0.32$ & $* 33.19 \pm 0.26$ & $* 29.98 \pm 0.81$ & $* 30.4 \pm 0.91$
\end{tabular}

$*(\mathrm{p}<0.00 \mathrm{I})$

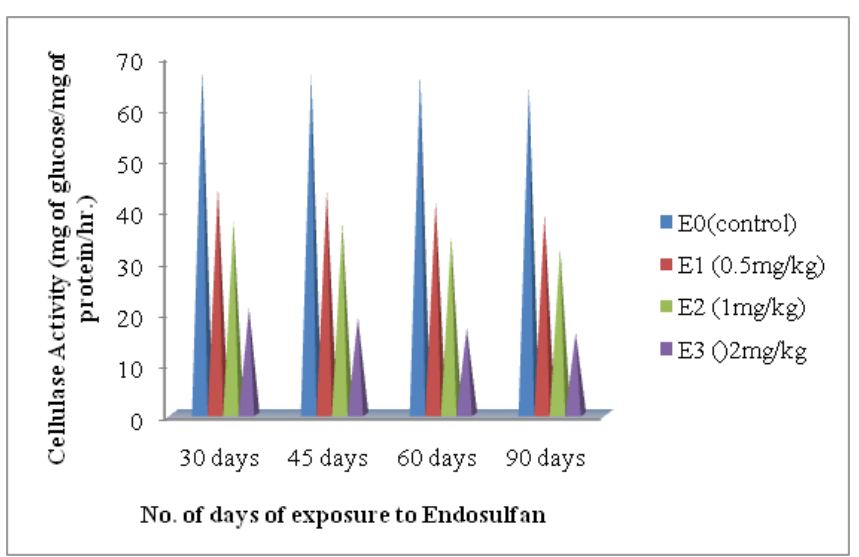

Figure 2 Showing the cellulase activity (mg of glucose/mg of protein/ hr.) of earthworms during 30,45, 60 and 90days of exposure to different concentrations of Endosulfan.

\section{Acetyl cholinesterase activity ( $\mu \mathrm{mol} / \mathrm{mg}$ of protein/ min)}

As evident from (Table 3) (Figure 3) endosulfan caused a significant decreased in AchE activity of earthworms of all the three groups i.e. E1, E2 and E3 except the control group E0. The dose of $0.5 \mathrm{mg} / \mathrm{kg}$ caused decrease in AchE activity up to $57 \%$ i.e. $(44.16 \pm 0.65 \mu \mathrm{mol} / \mathrm{mg}$ of protein $/ \mathrm{min})$ in comparison to control value $(76.19 \pm 0.27 \mu \mathrm{mol} / \mathrm{mg}$ of protein $/ \mathrm{min}$ ) over the 28 days. The next dose of $1 \mathrm{mg} / \mathrm{kg}$ caused a decrease in AchE activity up to $49 \%$ i.e. (37.56 \pm 3.53$)$ and the highest dose of $2 \mathrm{mg} / \mathrm{kg}$ brought about a maximum decrease in AchE activity up to $32 \%(24.97 \pm 0.89)$ during the entire period of 28 days. All the values were found to be significantly different from their relevant controls at $(\mathrm{p}<0.001)$.

Table 3 Showing the AchE activity ( $\mu \mathrm{mol} / \mathrm{mg}$ of protein/min.) of earthworms during $7,14,21$ and 28days of exposure to different concentrations of endosulfan (mean $\pm S$.E where $n=9$ ).

\begin{tabular}{|c|c|c|c|c|}
\hline Dosage & 7 Days & I 4 Days & 2 I Days & 28 Days \\
\hline Control) & $76.2 \pm 0.34$ & $76.15 \pm 0.66$ & $75.23 \pm 0.81$ & $76.19 \pm 0.27$ \\
\hline $\begin{array}{l}\mathrm{El}(0.5 \mathrm{mg} / \\
\mathrm{kg})\end{array}$ & $42.18 \pm 0.43$ & $41.29 \pm 2.36$ & $45.37 \pm 2.00$ & $44.16 \pm 1.07$ \\
\hline E2( $(\mathrm{mg} / \mathrm{kg})$ & $37.84 .85 \pm 0.39$ & $35.22 \pm 1.25$ & $35.78 \pm 1.310$ & $37.56 \pm 3.53$ \\
\hline $\mathrm{E} 3(2 \mathrm{mg} / \mathrm{kg})$ & $27.11 \pm 1.57$ & $23.66 \pm 0.50$ & $24.8 \pm 1.3$ & $24.97 \pm 0.89$ \\
\hline
\end{tabular}

$*(p<0.00 I)$

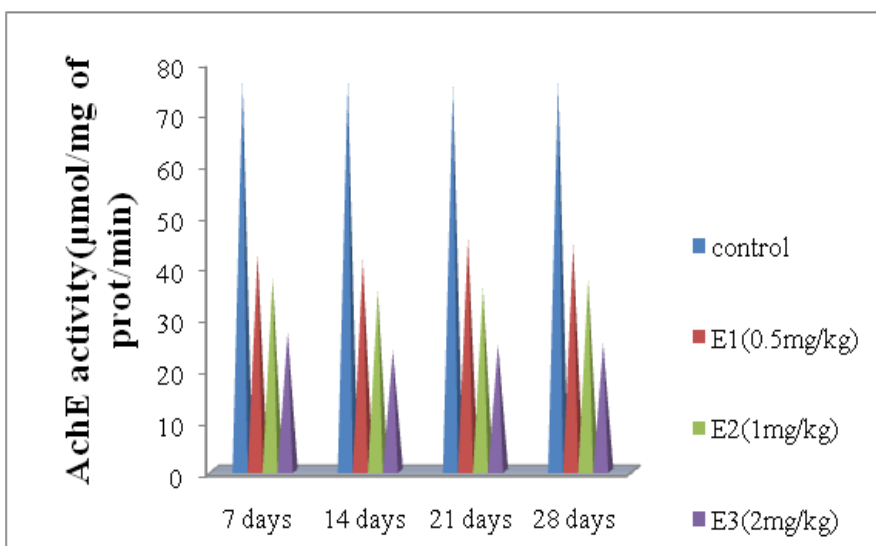

\section{No. of days of exposure to endosulfan}

Figure 3 Showing the change AchE enzyme activity ( $\mu \mathrm{mol} / \mathrm{mg}$ of protein/ min.) of earthworms during $7,14,21$ and 28days of exposure to different concentrations of endosulfan with well matched control earthworms.

\section{Acetyl cholinesterase activity ( $\mu \mathrm{mol} / \mathrm{mg}$ of protein/ min)}

In the present study according to the data of (Table 2) (Figure 4) endosulfan brought down the activity of AchE in earthworms of all the three exposed groups i.e. E1, E2 and E3 except the control group E0 during 30,45, 60 and 90days of exposure. At the dose of $0.5 \mathrm{mg} / \mathrm{kg}$ there was an initial decrease in AchE activity up to $48 \%$ i.e. $(57.64 \pm 0.37 \mu \mathrm{mol} / \mathrm{mg}$ of protein $/ \mathrm{min})$ in comparison to control value $(76.52 \pm 0.27 \mu \mathrm{mol} / \mathrm{mg}$ of protein $/ \mathrm{min})$ in first 30 days of exposure which later on restored up to $81 \%$ after 90 days and found to be $54.01 \pm 0.48$. The next dose of $1 \mathrm{mg} / \mathrm{kg}$ caused a decrease in AchE activity up to 57\% during 30days of exposure which later on increased and recovered up to $40 \%$ during 90 days of exposure. As evident from the data of (Table $2 \&$ Figure 4) the highest dose of $2 \mathrm{mg} / \mathrm{kg}$ brought about a maximum decrease in AchE activity up to $68 \%$ in first 30 days of exposure which later on increases and restored up to $44 \%$ after 90days of exposure and the values were found as $40.74 \pm 0.37$ and $30.04 \pm 0.91$ and found to significantly different at $\mathrm{p}<0.001$.

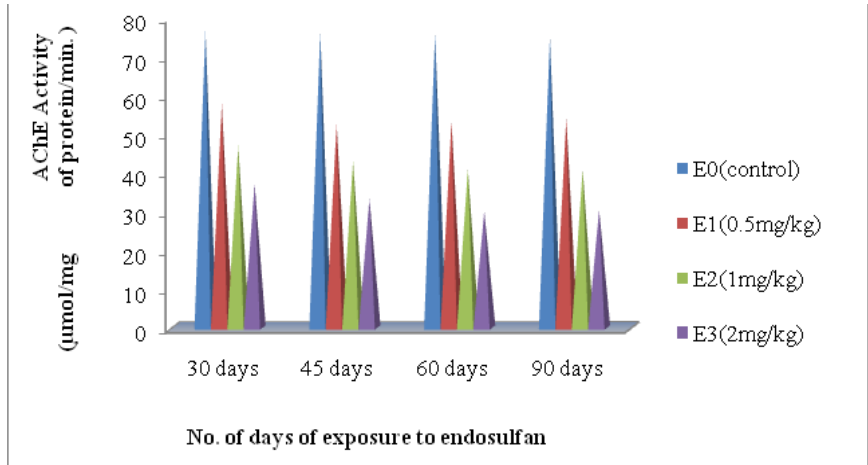

Figure 4 Showing the AchE activity ( $\mu \mathrm{mol} / \mathrm{mg}$ of protein/min.) of earthworms during 30,45, 60 and 90days of exposure to different concentrations of endosulfan (mean \pm S.E where $n=9$ ).

\section{Discussion}

In this study it has been found that different sublethal doses of 
endosulfan caused significant inhibition of AchE activity at $(\mathrm{p}<0.001)$ in earthworm E.foetida during the short term exposure period of $7,14,21$ and 28days as well as during the long term period of 30 , 45, 60 and 90days. The inhibition of AchE activity was found to be concentration dependent. During the exposure period of 28 days the percent of AchE activity was found as $43 \%, 51 \%$ and $68 \%$ at doses of $0.5,1$ and $2 \mathrm{mg} / \mathrm{kg}$ endosulfan whereas, during the exposure period of 30 to 90 days same doses caused inhibition of AchE activity up to $25 \%, 39 \%$ and $63 \%$ after first 30 days of exposure and no significant changes or recovery of enzyme activity was observed after 90days of exposure. Kumar et al., ${ }^{12}$ reported that the inhibition of AchE activity due to organochlorine pesticide like endosulfan has been studied for a wide range of species and has been accepted as index of toxicity in vivo. Organochlorine compounds interfere with nerve cell membrane cation transport resulting in neural irritability and excitation of central nervous system which ultimately affected the nerve transmission by suppressing the activity of acetylcholine esterase. It is known that it is not always the parent compound that causes the toxic effects on Chess activity but rather its metabolic products. From the results of present studies it has been concluded that, the effects produced by endosulfan were found to be long lasting and no significant repair and restoration of enzyme activity was observed even after 90days period of exposure at all the three selected sublethal doses of endosulfan which clearly shows that organochlorine pesticides have enormous potential to produce toxic effects in earthworms. Niklas, ${ }^{13}$ reported inhibition of AchE in earthworm L. terresris due to endosulfan toxicity and later on Scaps et al. ${ }^{14}$ reported the inhibition of AchE activity in L. terresris due to organochlorine pesticide gamma - $\mathrm{HCH}$, but decrease in AchE activity in earthworm due to organochlorine pesticides and its mechanics of inhibition is worth further study. In the present studies it has been found that both the pesticides i.e. dichlorovos and endosulfan caused significant decrease in acetyl cholinesterase activity at their relevant sublethal doses, moreover, both the above pesticides significantly affected the avoidance behavior of earthworm Eisenia foetida and therefore, the present investigations can be well correlated with the findings of Laura et al., ${ }^{15}$ who reported that inhibition of AchE activity by pesticides is another biomarker directly implicated in behavior perturbation. Earthworm body wall muscles present vertebrate like cholinergic neuromuscular junctions which contains the enzyme AchE for regulating synaptic transmission. Despite an intuitive connection between inhibition of muscle AchE activity by anti-ChE pesticides and perturbation in locomotors activity there are few studies that show such a relationship with earthworms.

\section{Effects of endosulfan on cellulase activity of earthworm E.foetida}

In the present study different sublethal doses of both the pesticides i.e. dichlorovos of organophosphate group and endosulfan of organochlorine group caused significant inhibition of Cellulase activity in earthworm E. foetida. The inhibition of Cellulase activity was found to be concentration dependent in response to different concentrations of both pesticides. During short term study of 7 to 28days of dichlorovos the percentage inhibition of Cellulase activity was found as $33 \%, 52 \%$ and $69 \%$ at 19,38 and $76 \mathrm{mg} / \mathrm{kg}$ after the first 7 days of exposure and no significant changes were observed during the period of 28days exposure as well and similar decrease in Cellulase activity was observed after 45 days of exposure during long term study period of 90days. Later on recovery in cellulose activity was observed after 60days at all concentrations of exposure. Moreover, after 90 days the Cellulase activity was seem to be completely recovered as there was no significant difference in control and treated values. Whereas, endosulfan caused gradual decrease in Cellulase activity during both short and long term period of studies and no recovery or restoration of enzyme activity was observed even after 90 days of exposure period. $E$. foetida is likely to feed mainly on manure and vegetal components the inhibition of cellulase enzyme due to the exposure of dichlorovos and endosulfan may because of reduction in feeding habits of earthworms during the exposure to pesticides thus reducing the substrate availability of the enzyme as the pesticides were mixed in the soil from where the exposed earthworms were obtaining their food or it may be due to the accumulation of pesticides in tissues of gut region where they interfere in catalytic action of enzyme. In both the cases it is evident that pesticides exposure produces hindrance in digestion and metabolic activities of earthworms and therefore decrease feeding will result in decrease growth and reproduction, which can severely affects the survival of population of earthworms ${ }^{16}$ and therefore the measurement of decreased Cellulase activity in earthworms which are dominant invertebrates of soil has potential as a biomarker of pesticide. Patnaik et al., ${ }^{17}$ reported the reduction in cellulose activity in three different species of earthworms i.e. L. mauritii, O.surensis and D.willsi when they were exposed to sublethal concentrations of organophosphate pesticide Malathion. Luo et al., ${ }^{6}$ studied the effects of different concentrations of pesticides i.e. imidacloprid and RH5849 on the activity of cellulase enzyme of E. foetida during the exposure period of $4 \mathrm{hrs}$. And found significant reduction in cellulase activity in comparison to control. On the contrary in the present investigation earthworm $E$. foetida has been exposed to pesticides for short term study period of 7 to 28 days as well as long term period of 30 to 90 days which is sufficient to monitor long term effects of toxic chemicals such as pesticides. In case of endosulfan no recovery or restoration of Cellulase activity was observed which might be due to the persistent nature of organochlorine pesticides in soil as well as due to bioaccumulation of pesticides in earthworms, as organochlorine pesticides are known for their property of bioaccumulation.

\section{Conclusion}

Therefore, from the present findings it can be concluded that long term exposure to organochlorine pesticides could lead to severe and irreparable effects on biochemical mechanisms of earthworms which is not a good sign for the growth and development of earthworms in pesticide contaminated field conditions. And therefore, infers a greater risk to cause decrease in earthworm population.

\section{Acknowledgements}

None.

\section{Conflict of interest}

The author declares no conflict of interest.

\section{References}

I. Rand GM, Petrocelli SR. Fundamentals of aquatic toxicology. USA: Hemisphere Publishing Corporation; 1985. p. I-666.

2. Ali Ayesha S, Kusha Chadha, Chanchla Devi, et al. Histological studies of some organs of earthworms treated with lead nitrate. Orient J Chem. 2002; $18(1): 121-124$.

3. Sameena Farrukh,Ayesha SA. Effects of Dichlorovos Organophosphate on Growth, Reproduction, and Avoidance Behavior of Earthworm Eisenia foetida. Iranian Journal of Toxicology. 20 I I;5( I4):495-50 I. 
4. Elaigwu SE, Ajibola VO, Folaranmi FM. Studies on the impact of municipal waste dumps on surrounding soils and air quality of two cities in northern Nigeria.J Appl Sci. 2007;7(3):42I-425.

5. Tripathi G, Kachhwaha N, Dabi I. Comparative studies on carbofuran - induced changes in some cytoplasmic and mitochondrial enzyme and proteins of epigeic, anecic and endogeie earthworms. Pestic Physiol. 2010;96:30-35.

6. Dell Omo G, Turk A, Shore RF. Secondary poisoning in the common shrew (Sorex araneus) fed earthworms exposed to an organophosphate pesticide. Environ Toxicol Chem. 1999; 18(2):237-240.

7. Booth LH, Heppelthwaite VJ, Halloran KO. Growth, Development and Fecundity of the earthworm Aporrectodea caliginosa, after exposure to two organophosphates. New Zealand Plant Protection. 2000;53:221-225.

8. Sameena Farrukh, Ayesha SA. Effects of Endosulfan an organochlorine pesticide on Growth, Reproduction, and Avoidance Behavior of Earthworm Eisenia foetida. Biosci Biotech Res Comm. 20I I;4(I):84-89.

9. Mishra PC, Dash Mc. Digestive enzymes of some earthworm. Experimentia. 1980;36(10):1156-1157.

10. Rao JV, Kavitha P. Toxicity of azodrin on the morphology and acety cholinesterase activity of the earthworm Eisenia foetida. Environmental research. 2004;96(3):323-327.

II. Ellman G L, Courtenay KD,Valentino AJ, et al.A new rapid colorometric determination of acetylcholinesterase activity. Biochem Pharmacol. 1961;7:88-95.
12. Kumar Neeraj, Antony P, Jesu Prabhu, et al. Anti-Oxidative and Immunoheamatological status of Tilapia (Oreochromis mossambicus) during toxicity test of endosulfan. Pesticide Biochemistry and Physiology. 2011;99:45-52.

13. Niklas Von J. Histochemishe unter suchungen zurwirkung von pestizidenals cholinesterase- inhibitoren bei Lumbricus terresris. $L Z$ Angew Zool. 1979:359-368.

14. Scaps P, Grelle C, Descamps M. Cadmium and lead accumulation of the earthworm Eisenia foetida (Savigny) and its impact on cholinesterase and metabolic pathway enzyme activity. Comp Biochem and Physiol. 1997; I 16(3):233-238.

15. Laura Rodriguez, Castellanos, Sanches Hernandez JC. Earthworm biomarkers of pesticide contamination: Current statics and perspectives.J Pestic Sci. 2007;32(4):360-37I.

16. Sameena Farrukh, Ayesha SA. Toxicological effects of organophosphate pesticide (Dichlorovos) on ceolomocytes viability of earthworm-E. foetida using Neutral red retention Assay. Iranian Journal of Toxicology. 2015;9(28): 1254-1257.

17. Patnaik HK, Dash MC.Activity of gut enzymes in three tropical grassland earthworm species exposed to sublethal malathion suspension. Bull Environ Contam Toxicol. 1993;5 I(5):780-786. 